RASĀYAN J. Chem.

Vol. 13 | No. 3 |1308-1312| July - September | 2020 ISSN: 0974-1496 | e-ISSN: 0976-0083 | CODEN: RJCABP

\title{
HUMATES FROM COAL MINING WASTE: SYNTHESIS, STUDY OF COMPOSITION AND RADIOACTIVITY
}

\author{
M. Kambatyrov, U. Nazarbek, P. Abdurazova, S. Nazarbekova \\ and Y. Raiymbekov" \\ Department of Chemical Technology of Inorganic Substances, M.Auezov South Kazakhstan \\ State University, 160000, Shymkent, Kazakhstan \\ *E-mail: eraiymbekov@gmail.com
}

\begin{abstract}
This article investigates the possibility of extracting humate from the waste of coal mining of brown coals of the Lenger deposit with the addition of several types of hydroxides, their microstructure and chemical composition were studied, the obtained humates were studied for radioactivity to determine their practical applicability in the production of organo-mineral fertilizers and feed additives.
\end{abstract}

Keywords: Coal Mining Waste, Humate, Radioactivity, Feed Additives, Calcium Humate.

(C) RASĀYAN. All rights reserved

\section{INTRODUCTION}

Humic substances are almost everywhere in nature. This is the main organic component of soil, water, and solid fuels. Humic acids are found in rocks such as brown coal, sapropel and peat. Brown coal contains the most humic acids up to $86 \%$, that is, waste from brown coal mining is the main source of humic substances, and this solves many environmental problems ${ }^{1}$.

Humates are part of humic substances, which are salts of humic acids. Humates have common properties for all humic substances: polydispersity, irregular structure and polyfunction. These properties are manifested by a combination in the molecular structure of the aromatic core and hydrophilic periphery, consisting mainly of aliphatic, oligosaccharide and oligopeptide fragments ${ }^{2}$. Humates are also called a large group of drugs made from easily soluble salts of humic acids. These drugs are used in crop production $^{3}$, animal husbandry ${ }^{4}$, medicine ${ }^{5}$, construction ${ }^{6}$, drilling, ecology, land reclamation and restoration ${ }^{7}$, in the production of organo-mineral fertilizers ${ }^{8}$.

According to the literature ${ }^{9}$ humic substances when used as feed additives improve the effectiveness of feed products by normalizing the intestinal microflora of animals: the growth of live weight in them occurs without increasing the rate of feed consumption. Humates have an adsorbing effect: they bind toxic substances in the gastrointestinal tract and contribute to their rapid elimination while increasing the body's protective abilities.

Humates have an immunostimulatory effect, enhancing the process of phagocytosis in animals (absorption and isolation of harmful cells or microorganisms). Another amazing ability of humates: they increase the endurance and adaptive capacity of the body in conditions of physical and emotional overload, helping to cope with the consequences of stressful situations ${ }^{10}$. Summing up all the advantages of humic preparations, we can confidently say that their use will significantly increase the productivity of livestock and poultry, as well as improve the quality characteristics of the resulting meat and dairy products, eggs, wool and other agricultural products based on them.

The Lenger brown coal deposit is located in the southern region of Kazakhstan. According to the stock carrying part of it is 33956 thousand tons, and off-balance- 3244 thousand tons by the extraction of this hydrocarbon formed a waste of more than 6 million tons ${ }^{11}$.

It is established that the main components of brown coal waste from the Lenger deposit are mineral and organic substances. The mineral part is represented by the components of siliceous, aluminate and Rasayan J. Chem., 13(3), 1308-1312(2020)

http://dx.doi.org/10.31788/RJC.2020.1335729

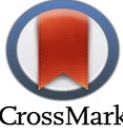


RASĀYAN J. Chem.

Vol. 13 | No. 3 |1308-1312| July - September | 2020

calcium compounds. The organic part of brown coal waste is represented by functional groups of organic substances, including humic compounds, in combination with organometallic substances. The hydrocarbon part of brown coal waste is a mixture of high-molecular compounds of non-permanent composition, from aromatic and heterocyclic structures of low degree of condensation, connected by bridges $-\mathrm{CH}_{2}-,-\mathrm{O}-,-\mathrm{S}-$ with functional groups of aliphatic and hydroaromatic fragments ${ }^{11}$.

The purpose of this study is to be able to extract humates from the coal mining waste of the Lenger coal field with the addition of $\mathrm{KOH}, \mathrm{Ca}(\mathrm{OH})_{2}, \mathrm{NaOH}, \mathrm{KOH}$ and $\mathrm{NaOH}$ together for potassium, calcium, sodium, potassium and sodium humate and study their composition.

\section{EXPERIMENTAL}

Methods of Research

Microstructural and element-weight studies were performed using modern SEM equipment (scanning electron microscope JEOl, brand JSM6490 LV).

IR-spectral analysis of humates was performed on the Specord-75 IR spectrophotometer, which automatically registers the infrared absorption spectra of the studied samples in the range of wave numbers.

Spectrometric measurements of the activity of gamma-emitting radionuclides in the resulting humates were performed on the Progress BG gamma-beta spectrometric complex.

\section{General Procedure}

Based on laboratory studies a technological scheme for obtaining potassium humate was developed, which is shown in accordance with Fig.-1.

The coal mining waste from the Lenger field is loaded into a ball mill (1), where it is thoroughly crushed and sent to a screen (2), where the coal mining waste is obtained with an average size of 100 microns - 1 $\mathrm{mm}$.

The crushed waste of coal mining, then sent to the collection (3) from there, the pneumatic pump (4) is sent to the flow meter (5). In the reactor (7), equipped with an electric stirrer and a steam jacket from the collector (3), coal mining waste is loaded, then a predetermined flow rate of $1 \%$ aqueous solution of hydroxide (potassium, calcium, sodium, potassium and sodium alternately) is fed from position (6).

The process of leaching the raw material is carried out in the reactor (7) with continuous stirring at a temperature of $80^{\circ} \mathrm{C}$ for 2 hours. As a result of the leaching of coal mining waste, humate (potassium, calcium, sodium, potassium and sodium) is formed. The product precipitated is collected in the collector (8).

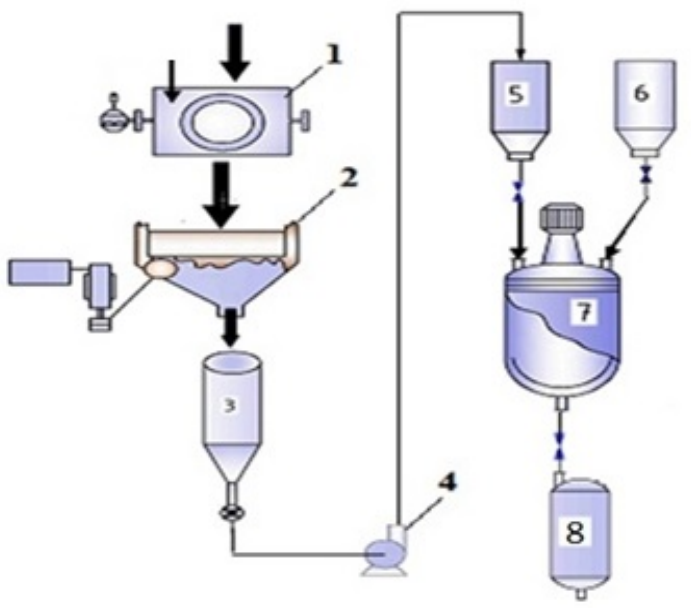

Fig.-1: Scheme for Obtaining Humates From Coal Mining Waste: 1-Ball Mill; 2-Screen; 3-Collection; 4-Pneumatic pump; 5-Flowmeter of Coal Mining Waste; 6-Flowmeter 1\% $\left(\mathrm{KOH}, \mathrm{Ca}(\mathrm{OH})_{2}, \mathrm{NaOH}, \mathrm{KOH}\right.$ and $\mathrm{NaOH}$ together); 7 -

Reactor for Producing Humate (Potassium, Calcium, Sodium, Potassium and Sodium); 8-Collection of Humate

(Potassium, Calcium, Sodium, Potassium and Sodium) 
RASĀYAN J. Chem.

Vol. 13 | No. 3 |1308-1312| July - September | 2020

According to the developed technological scheme, humate is obtained in the form of a liquid-phase colloidal mixture, which consists of humate (potassium, calcium, sodium, potassium and sodium) and dissolved mineral components of coal mining waste-compounds of potassium, sodium, iron, sulfur, etc.

\section{RESULTS AND DISCUSSION}

To determine the qualitative composition of the organic part, the resulting product was subjected to IR spectral analysis on the device Specord-75 IR in the range of 4000-450 $\mathrm{cm}^{-1}$. At the same time, before each IR spectral analysis, the free part of the water was removed from the composition of the resulting humate (potassium, calcium, sodium, potassium and sodium) by evaporation to obtain a liquid phase-pH 0.883. The results of these studies are shown in accordance with Fig.-2.

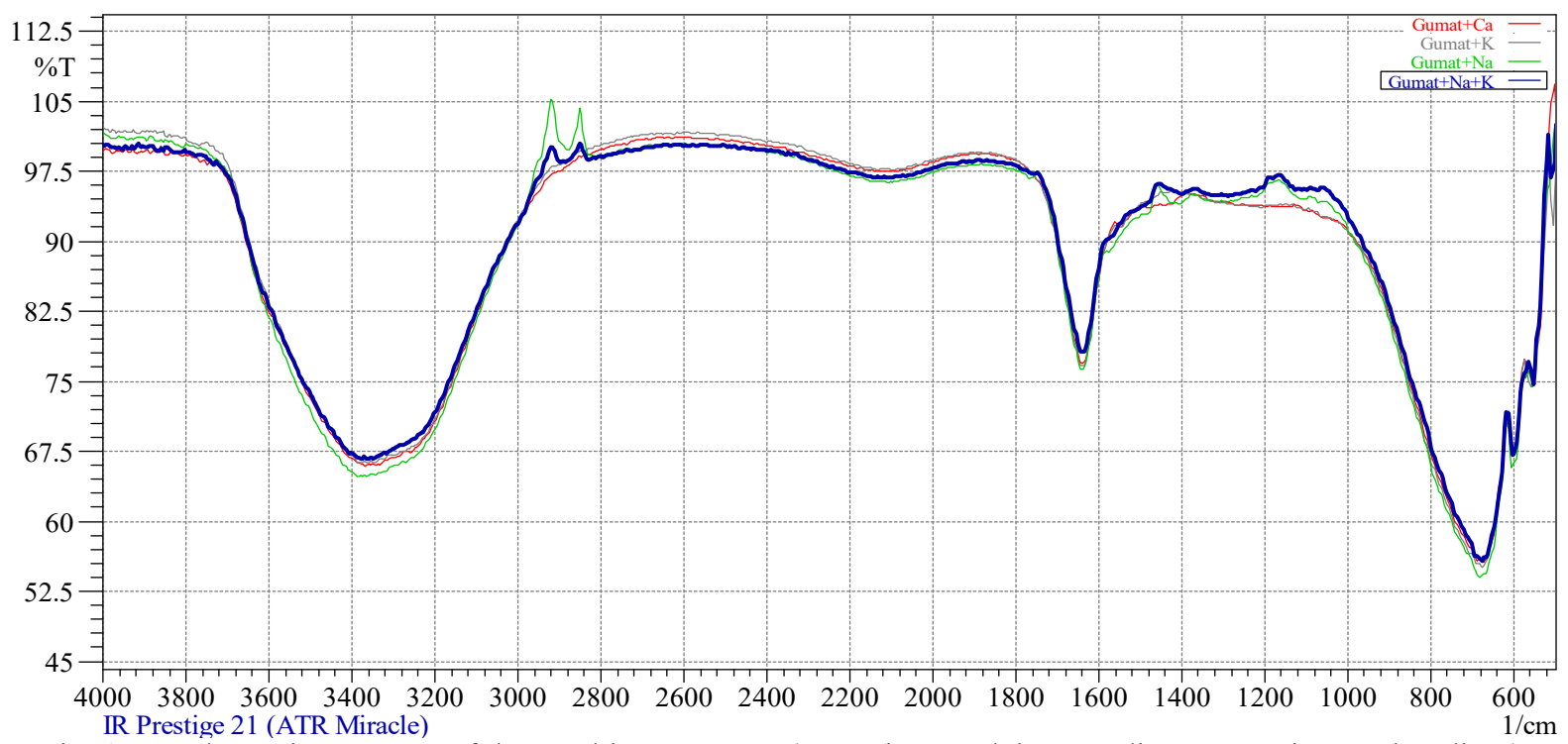

Fig.-2: IR Absorption Spectra of the resulting Humates (Potassium, Calcium, Sodium, Potassium and Sodium)

IR spectra are characterized by two intense absorption bands in the region of $600 \mathrm{~cm}^{-1}$. The first absorption region determines the impurity deformation oscillations characteristic of the valence groups of silicates and aluminates. So the absorption bands in the area of 551-601 $\mathrm{cm}^{-1}$ group Si-O-Al.

Non-intensive absorption bands in the region of $1639 \mathrm{~cm}^{-1}$ correspond to the deformation fluctuations of the group-C-H with the inclusion of methyl, methylene and methine compounds. A wide absorption band in the area of 3363-3400 $\mathrm{cm}^{-1}$ indicates the presence of a hydroxyl group of compounds with intermolecular hydrogen bond $\mathrm{O}-\mathrm{H}$, as well as an $\mathrm{OH}$ group with inclusions of polyassociates of potassium humates, calcium, sodium, potassium and sodium.

As noted above, the composition of the isolated humate (potassium, calcium, sodium, potassium and sodium), in addition to organic compounds, also contains minerals. The element and mineralogical compositions were analyzed on the JEOl electron microscope in the 40 -fold magnification spectrum. The results of the research are shown in Table-1 and Fig.-3.

Table-1: Elemental Composition of Humates (Potassium, Calcium, Sodium, Potassium and Sodium)

\begin{tabular}{c|c|c|c|c|c|c|c|c}
\hline \multirow{2}{*}{ Compounds } & \multicolumn{7}{c}{ Elements, \% } & \multicolumn{2}{c}{$\mathrm{K}$} & $\mathrm{Ca}$ \\
\cline { 2 - 10 } & $\mathrm{C}$ & $\mathrm{O}$ & $\mathrm{Na}$ & $\mathrm{Al}$ & $\mathrm{Si}$ & $\mathrm{S}$ & $\mathrm{K}$ & - \\
\hline Potassium humate & 12.59 & 37.90 & 0.40 & 0.60 & 2.17 & 0.10 & 46.24 & - \\
\hline Sodium humate & 14.25 & 44.33 & 37.13 & 0.62 & 2.76 & 0.18 & 0.74 & - \\
\hline Calcium humate & 10.07 & 42.39 & 0.30 & 1.39 & 2.46 & 0.34 & 0.33 & 42.12 \\
\hline Potassium and sodium humate & 13.66 & 39.66 & 16.90 & 0.40 & 1.77 & 0.15 & 27.46 & - \\
\hline
\end{tabular}


RASĀYAN J. Chem.

Vol. 13 | No. 3 |1308-1312| July - September | 2020

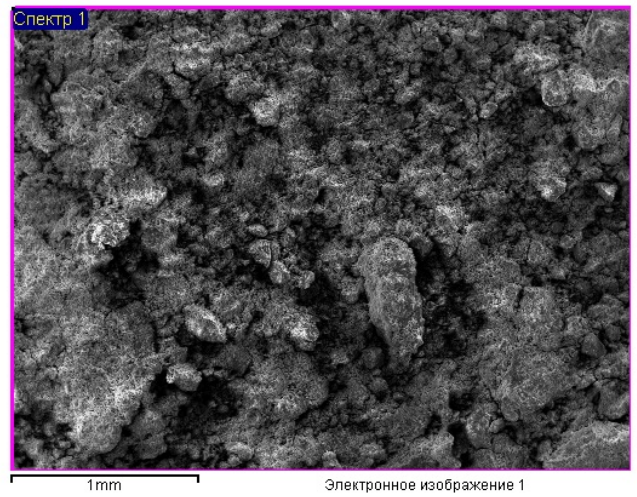

Potassium Humate

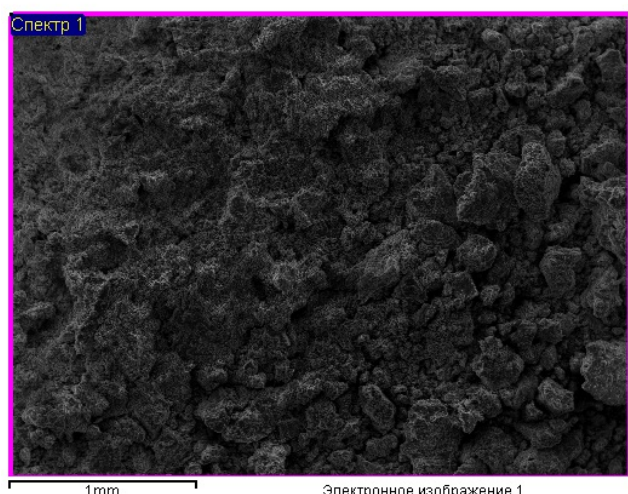

Sodium Humate

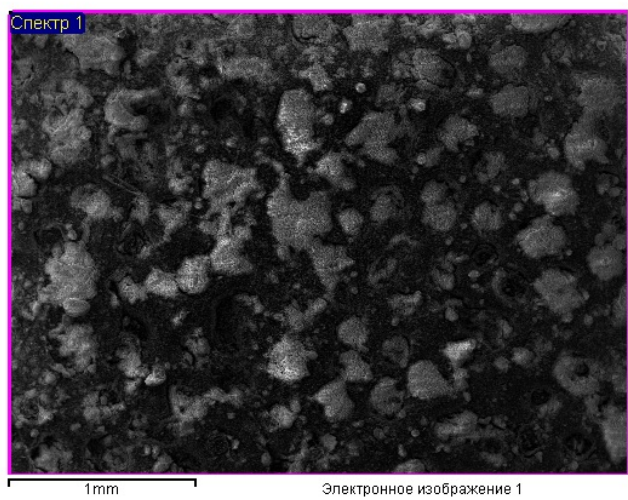

Calcium Humate

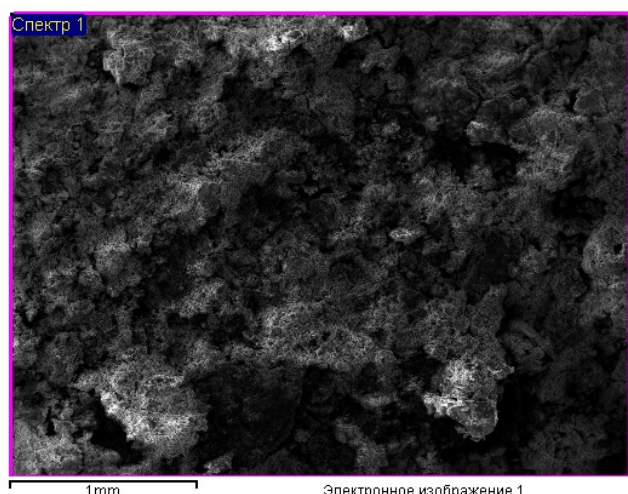

$\mathrm{Na}+\mathrm{K}$ Humates

Fig.-3: Microstructure of Humates (Potassium, Calcium, Sodium, Potassium and Sodium) at An Increase of 40 Times

The microstructure and element composition of humates (potassium, calcium, sodium, potassium and sodium) have a clear basis of minerals in the form of island bulk structures up to $85 \%$ of the total mass. Some inclusions of quartz and aluminosilicate are observed on the surface of humate minerals (potassium, calcium, sodium, potassium and sodium).

The practical application of humates in agriculture, in particular in the production of organic fertilizers, animal husbandry and poultry farming, has fully confirmed their antibacterial and antiviral protective properties. This is confirmed by the results of the study of humates for radioactivity by gamma-beta spectroscopy, where the level of radionuclides is one hundred times less than the permissible norm.

Table-2: Results of the Measurement of Humic Substances on Radioactivity

\begin{tabular}{|c|c|c|c|c|}
\hline Name of Sample & Name of Indicators & Unit & $\begin{array}{c}\text { Specific Effective } \\
\text { Activity of } \\
\text { Radionuclides }\end{array}$ & $\begin{array}{c}\text { Permissible } \\
\text { Content }\end{array}$ \\
\hline Potassium humate & $\begin{array}{c}\text { Cesium-137 } \\
\text { Strontium-90 }\end{array}$ & $\begin{array}{l}\mathrm{Bq} / \mathrm{kg} \\
\mathrm{Bq} / \mathrm{kg}\end{array}$ & $\begin{array}{l}<1.8 \\
<0.56\end{array}$ & $\begin{array}{l}180.0 \\
100.0\end{array}$ \\
\hline Sodium humate & $\begin{array}{l}\text { Cesium-137 } \\
\text { Strontium-90 }\end{array}$ & $\begin{array}{l}\mathrm{Bq} / \mathrm{kg} \\
\mathrm{Bq} / \mathrm{kg}\end{array}$ & $\begin{array}{l}<2.4 \\
<0.56\end{array}$ & $\begin{array}{l}180.0 \\
100.0\end{array}$ \\
\hline Calcium humate & $\begin{array}{c}\text { Cesium-137 } \\
\text { Strontium-90 }\end{array}$ & $\begin{array}{l}\mathrm{Bq} / \mathrm{kg} \\
\mathrm{Bq} / \mathrm{kg}\end{array}$ & $\begin{array}{l}<4.05 \\
<0.56\end{array}$ & $\begin{array}{l}180.0 \\
100.0\end{array}$ \\
\hline $\begin{array}{l}\text { Potassium and sodium } \\
\text { humate }\end{array}$ & $\begin{array}{l}\text { Cesium-137 } \\
\text { Strontium-90 }\end{array}$ & $\begin{array}{l}\mathrm{Bq} / \mathrm{kg} \\
\mathrm{Bq} / \mathrm{kg}\end{array}$ & $\begin{array}{l}<1.8 \\
<0.56\end{array}$ & $\begin{array}{l}180.0 \\
100.0\end{array}$ \\
\hline
\end{tabular}

1311 
RASĀYAN J. Chem.

Vol. 13 | No. 3 |1308-1312| July - September | 2020

\section{CONCLUSION}

The results obtained allow us to establish the nature of the redistribution of Cs-137 and Sr-90 in humates for further use in the production of organo-mineral fertilizers and feed additives. The specific radioactivity of Cs-137 and Sr-90 is much lower in potassium, potassium, and sodium humate. This is because potassium ions are less weak than sodium ions. In this regard, for the production of organomineral fertilizers and feed additives, potassium humate, synthesized from coal mining waste, is optimal.

\section{REFERENCES}

1. B.A. Comes de Melo, F.L. Motta and M.H. Andrade Santana, Material Science and Engineering: C., 62, 967(2016), DOI: 10.1016/j.msec.2015.12.001

2. S.I. Zherebtsov, N.V. Malyshenko, K.S.Votolin, V.A. Androkhanov, D.A. Sokolov, J. Dugarjav and Z. R. Ismagilov, Solid Fuel Chemistry, 53, 145(2019), DOI:10.3103/S0361521919030121

3. O.S. Bezuglova, A.V. Gorovtsov, E.A. Polienko, V.E. Zinchenko, A.V. Grinko, V.A. Lykhman, M.N. Dubinina, and A. Demidov, Journal of Soils and Sediments, 19, 2665(2019), DOI:10.1007/s11368$018-02240-z$

4. A.R.P. Disetlhe, U. Marume, V. Mlambo and A.Hugo, Asian-Australasian Journal of Animal Sciences, 32, 711(2019), DOI:10.5713/ajas.18.0408

5. N. Stepanov, O. Senko, I. Perminova and E. Efremenko, Sustainability, 11, 3158(2019), DOI: $10.3390 /$ su11113158

6. N. Narlioglu, T. Salan, E. Karaogul and M.H. Alma, Kastamonu University Journal of Forestry Faculty, 18, 189(2018), DOI:10.17475/kastorman.346857

7. T.V. Minnikova, S.I. Kolesnikov and T.V. Denisova, South of Russia: Ecology, Development, 14, 189(2019), DOI:10.18470/1992-1098-2019-2-189-201

8. U. Besterekov, K.K. Nurasheva, U.B. Nazarbek, S.P. Nazarbekova and A.A. Bolysbek, Oriental Journal of Chemistry, 33, 92(2017), DOI:10.13005/ojc/330110

9. M.A.Yörük, M.Gül, A.Hayirli and M.Macit, Poultry Science, 83, 84(2004), DOI:10.1093/ps/83.1.84

10. B.Pisarikova, Z.Zraly and I.Herzig, Acta Veterinaria Brno, 79, 349(2010), DOI: $10.2754 / \mathrm{avb} 201079030349$

11. E.B.Raiymbekov, T. Ryskulov, U.B. Nazarbek, U. Besterekov and I.A. Petropavlovskiy, Chemical Journal of Kazakhstan, 4, 336(2016), DOI:2016/04/2016-4-36

[RJC-5729/2020] 